\title{
Water Requirements of Creole Cucumber (Cucumis sativus L.) under Drip Irrigation in Corozal-Sucre
}

\author{
Euriel Millan-Romero, Ismael Sandoval-Assia and Carlos Millan-Paramo \\ Faculty of Engineering, University of Sucre, Sincelejo, Colombia; \\ euriel.millan@unisucre.edu.co, ismael.sandoval@unisucre.edu.co, carlos.millan@unisucre.edu.co
}

\begin{abstract}
Objectives: To determine the evapotranspiration and crop coefficient of creole cucumber under a drip irrigation system in Corozal (Department of Sucre, Colombia). Methods: The water requirement was determined using the gravimetric method; evapotranspiration was determined by water balance equation and climate record (evaporimeter); the crop coefficient (Kc) was calculated with the equation that relates crop Evapotranspiration (ETc) and reference Evapotranspiration (ETo). The experimental layout of the study was a split-plot design with 2 treatments and 3 replications. Treatment 1 (T1) consisted in the application of daily irrigation and Treatment 2 (T2) in the application of a sheet accumulated every three days. Findings: The evapotranspiration by water balance were 3.17 (T1) and $2.93 \mathrm{~mm} /$ day (T2); and by climate record was $2.14 \mathrm{~mm} /$ day. The crop coefficient for water balance was 0.89 and 0.87 , respectively in each treatment. The total water applied was $78.52 \mathrm{l} /$ plant for each treatment; the average yields were 20.26 and $20.24 \mathrm{t} /$ ha for treatments 1 and 2 respectively. Application: The evapotranspiration and crop yield did not show significant differences between the irrigation treatments. The technology of drip irrigation allowed a frequent application of small amounts of water that approach the rate of absorption of water by the crop, becoming an effective option to improve the nutritional regimen and life of the region.
\end{abstract}

Keywords: Cucumber, Crop Coefficient, Evapotranspiration, Water Requirements, Yield

\section{Introduction}

In Colombia, specifically in the Caribbean zone, agricultural activity develops without a sustainable interrelated management of soil-water-plant resources causing a notable imbalance that decreases the quality of production. The situation is evident in the horticultural sector. The perishable nature of these products leads to the idea of improving the exploitation techniques of this sector. Therefore, it is necessary to overcome the effects produced by climate change and to eliminate the dependence of climatic seasonality on the production of vegetables such as cucumber, because it causes alarming oscillations between supply and demand.

Cucumber belongs to the Cucurbitaceae family and its scientific name is Cucumis sativus L. From the germination to the first harvests, according to the biological peculiarities of the varieties and the conditions in which planted, it usually takes 45 to 70 days. The main root reaches a depth of $120 \mathrm{~cm}$ and at a depth of $25 \mathrm{~cm}$ to 30 $\mathrm{cm}$ from the ground level, a large number of lateral roots develop and spread horizontally, which determines a high demand of the plant with respect to the moisture balance. The cucumber has an abundant foliar system generating excessive water expenditure (transpiration), causing it to be demanding in soil moisture and aeration ${ }^{1}$.

Cucumber, because it is a tropical species, requires high temperatures and high relative humidity. However, it adapts to warm and temperate climates, which allows it to be cultivated from coastal areas up to $1200 \mathrm{~m}$ above sea level. At more than $40^{\circ} \mathrm{C}$ the growth stops, with temperatures lower than $14^{\circ} \mathrm{C}$, the growth stops and in case of prolonging this temperature, the feminine flowers fall. Due to this, the proper management of climatic factors

${ }^{*}$ Author for correspondence 
together is fundamental for the proper functioning of the crop $^{2}$ Turkey, in 2007. In the study, water was applied to cucumber as $100,75,50,25$ and $0 \%$ (as control.

The well-planned irrigation becomes part of the solution allowing knowing the productive behavior of the plants subjected to different conditions of humidity. Therefore, drip irrigation is an important option. The advantages of this type of irrigation are: greater control and efficiency in the use of water; higher productivity; better sanitary control; possibility of operating full time; keeps soil close to field capacity; less development of harmful herbs between crop lines; adaptation to different types of soil and topographies; decreases surface runoff, among others ${ }^{3}$.

It is very important to know the water requirements of the cucumber crop in its different phenological stages, as well as the influence of a water deficit on crop yields 4. These crops need adequate water nutrition that can guarantee the genetic expression of different species and

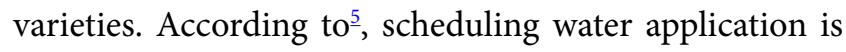
very critical to make the most efficient use of drip irrigation systems, as excessive irrigation water reduces yield while inadequate irrigation causes water stress and reduces production.

Several researchers have been studied the water requirements of cucumber. For example ${ }^{2}$ Turkey, in 2007. In the study, water was applied to cucumber as 100,75 , 50,25 and $0 \%$ (as control determined effect of deficit irrigation on yield for cucumber grown under unheated greenhouse condition; Blanco and Folegatti ${ }^{1}$ evaluated the evapotranspiration and crop coefficient of cucumber in greenhouse in Piracicaba (Brazil) ${ }^{6}$; evaluated the yield and quality of six long fruit type cucumber genotypes in Costa Rica ${ }^{4}$; estimated crop water requirements of cucumber at different phenological stages, using tub evaporation in Venezuela ${ }^{7}$; evaluated the yield and water use efficiency of cucumber conducted under subsurface drip irrigation system in a Mediterranean climate ${ }^{8}$; realized a estimation of cucumber evapotranspiration in solar greenhouse in Northeast China'; determined the most appropriate irrigation application and water use efficiency programs based on Class A Pan evaporation for mini type cucumber plants grown as a first crop under protected conditions in a solar greenhouse.

The aim of this study is to determine the evapotranspiration and crop coefficient of creole cucumber under a drip irrigation system in Corozal (Department of Sucre, Colombia).

\section{Materials and Methods}

\subsection{Localization, Soil Properties and Irrigation}

The study was done in 2017 in the farm "La Cucharita" in Corozal (Department of Sucre, Colombia), with altitude of 166 meters above sea level, climate of tropical dry forest with average temperature of $28{ }^{\circ} \mathrm{C}$ and average precipitation of $1200 \mathrm{~mm}$.

Soil was of clay loam texture with percentages of clay, silt and sand of 29.33, 33.67 and 37\%, respectively, has an Ap horizon 0-25 cm of thick, with good internal drainage. The chemical characteristics presents a neutral reaction, cation exchange capacity and very high total bases, saturation with high calcium and magnesium, low salinity and low contents of potassium, carbon and phosphorus.

A drip irrigation system was used with a $41 / \mathrm{h}$ dripper. Through the uniformity coefficient method $(92.87 \%)$ the irrigation system was evaluated to obtain the combinations of pressures and flows that guaranteed a uniform distribution of irrigation in the soil.

The sowing of the crop, harmful herbs control and the harvest of fruits was done manually. Three seeds were deposited per site at a depth of $2.5 \mathrm{~cm}$ and it was fertilized according to the balance of the soil and the needs of the crop.

\subsection{Application of Irrigation}

The times of irrigations and the applied sheets were calculated according to the needs of the crop in each one of the stage of the vegetative period, considering the radical depth; also, the operating pressure of the drippers.

With the application of irrigation, good humidity conditions were given to the plants and optimum levels were reached to the dripper line, a depletion coefficient of $30 \%$ of usable water and $33 \%$ of wetting was used. When there were rainy conditions in the development of the experiment, it was added as a uniform irrigation, in case of insufficiency a supplement irrigation sheet was applied. To decide the time and the amount of water, the hydrodynamic parameters of the soil (FC and PWP) were considered.

The effective root depths for the creole cucumber were: $1.5 \mathrm{~cm}$ in the first 11 days; $2.7 \mathrm{~cm}$ between 11 and 18 days; $3.10 \mathrm{~cm}$ between 18 and 28 days; and $4.15 \mathrm{~cm}$ after 28 days. With the values of field capacity, permanent 
wilting point, effective root depth, exhaustion coefficient and percentage of wetting, the irrigation sheet was determined in each irrigation as follow:

$$
N S=\frac{D C \cdot P w \cdot(F C-P W P) \cdot R d \cdot B d}{100}
$$

where NS is the net sheet; DC the depletion coefficient; FC the field capacity; PWP is the permanent wilting point; $\mathrm{Pw}$ is the percentage of wetting; $\mathrm{Rd}$ is the radical depth and Bd is the bulk density.

\subsection{Humidity}

The humidity (gravimetric method) was determined as follow

$$
\% W=\frac{(W s w-D s w)}{D s w} \times 100
$$

where Wsw is the wet soil weight and Dsw is the dry soil weight.

\subsection{Evapotranspiration by the Soil Water Balance}

Evapotranspiration was determined using the water balance equation that includes water loss and gain, precipitation and irrigation expressed in $\mathrm{mm}$ as well as humidity. The deep percolation and the runoff are null in drip irrigation. The capillary rise is null because the water level was very deep.

$$
\mathrm{ETP}=\mathrm{P}+\mathrm{I}-\Delta \mathrm{S}-\mathrm{Sr}-\mathrm{Dp}+\mathrm{U}
$$

Where, ETP is the evapotranspiration, $\mathrm{P}$ is the effective precipitation; I is the irrigation; is the change in soil moisture content; $R$ is the surface runoff; $D p$ is the deep percolation and $\mathrm{U}$ is the upward capillary rise.

\subsection{Crop Coefficient}

The crop coefficient $(\mathrm{Kc})$ was calculated as follow:

$$
\mathrm{Kc}=\mathrm{ETc} / \mathrm{ETo}
$$

where ETc is the evapotranspiration of the crop and ETo is the reference evapotranspiration.

\subsection{Crop Evapotranspiration}

First, the reference Evapotranspiration (ETo) was calculated as follow:

$\mathrm{ETo}=\mathrm{Kp} \cdot \mathrm{Epa}$ where $\mathrm{Kp}$ is the pan coefficient and Epa is the pan evaporation ( $\mathrm{mm} /$ day).

Then, the crop Evapotranspiration (ETc) was calculated from the ETo according to:

$\mathrm{ETc}=\mathrm{Kc} \cdot \mathrm{ETo}$

\subsection{Statistical Analysis}

The experimental layout of the study was a split-plot design with 3 replications, in which the main plots were the crop, and the subplots the irrigation sheets. Treatment 1 (T1) consisted in the application of daily irrigation and Treatment 2 (T2) in the application of a sheet accumulated every three days. Area of the plots for the determination of the water requirements of the creole cucumber was $184.32 \mathrm{~m}^{2}$ ( $\left.14.4 \times 12.8 \mathrm{~m}\right)$. In turn, these plots are divided into three subplots of $51.84 \mathrm{~m}^{2}$. There were also pasture plots $9 \times 3 \mathrm{~m}$, which in turn it was divided into three subplots of $3 \times 3 \mathrm{~m}$ for each treatment, in order to determine the reference evapotranspiration. The data were subjected to analysis of variance, correlations, regressions and mean test.

\section{Results and Discussion}

\subsection{Analysis and Description of Soil}

Before the establishment of the crop and to determine the sheet of water and the fertilization plan, the physical and chemical properties of the soil were determined (Table 1). In the project area there is only one type of soil texture (clay loam), which is beneficial for the normal development of the crop ${ }^{10}$. Also, it presented a high cation exchange capacity therefore a permanent technical assistance was required for its fertilization and good soil management to avoid the degradation. The chemical properties show that there are low amounts of nitrogen, phosphorus and potassium with respect to the nutritional needs of the crop to be implanted, hence it was necessary to correct these deficiencies by adding $1.702 \mathrm{~g}$ of N/ plant, $7.3 \mathrm{~g}$ of KCE/plant and $2.02 \mathrm{~g}$ of agrimins (fertilizer composed of micronutrients and Secondary nutrients supplemented with nitrogen and phosphorus)/plant.

\subsection{Irrigation Water Quality}

According to the water analysis for irrigation it was found that it was slightly conditioned by the quantity of soluble 
solids and sodium, so there was no problem since the cucumber is a salt tolerant plant ${ }^{11}$. According to the values of SAR (sodium adsorption ratio) and EC (electrical conductivity) the water is of good quality and recommended for irrigation, it belongs to the class $\mathrm{C} 2 \mathrm{~S} 1$ according to classification of the quality of water for irrigation ${ }^{12}$.

Table 1. Physical and chemical properties

\begin{tabular}{|l|l|}
\hline Soil variables & Value \\
\hline Depth $(\mathrm{cm})$ & $0-20$ \\
\hline Texture & Clay loam \\
\hline Clay $(\%)$ & 29.33 \\
\hline Silt $(\%)$ & 33.67 \\
\hline Sand $(\%)$ & 37.00 \\
\hline Bulk density $\left(\mathrm{g} \mathrm{cm}^{-3}\right)$ & 1.2 \\
\hline Field capacity $(\%)$ & 37.75 \\
\hline Wilting point $(\%)$ & 18.68 \\
\hline Usable water $(\%)$ & 19.07 \\
\hline Basic infiltration $(\%)$ & 15.47 \\
\hline $\mathrm{MO}(\%)$ & 2.32 \\
\hline $\mathrm{pH}(1: 1)$ & 7.72 \\
\hline $\mathrm{CEC}(\mathrm{meq} / 100 \mathrm{~g})$ & 28.00 \\
\hline $\mathrm{Ca}(\mathrm{meq} / 100 \mathrm{~g})$ & 16.25 \\
\hline $\mathrm{Mg}(\mathrm{meq} / 100 \mathrm{~g})$ & 11.25 \\
\hline $\mathrm{K}(\mathrm{meq} / 100 \mathrm{~g})$ & 0.006 \\
\hline $\mathrm{Na}(\mathrm{meq} / 100 \mathrm{~g})$ & 0.39 \\
\hline $\mathrm{P}(\mathrm{ppm})$ & 24.7 \\
\hline
\end{tabular}

\subsection{Evapotranspiration and Crop Coefficient}

The Evapotranspiration (ETc) and crop coefficient (Kc) of cucumber were determined from August 14, 2017 until September 29, 2017. Table 2 shows the mean value and mean daily value of real crop Evapotranspiration (ETc) of creole cucumber, determined by water balance and evaporimeter. For T1 and T2 a mean daily evapotranspiration of $3.17 \mathrm{~mm} /$ day and $2.93 \mathrm{~mm} /$ day was obtained, respectively. The total mean evapotranspiration of T1 (148.76 $\mathrm{mm}$ /day) is greater than the $\mathrm{T} 2(137.6 \mathrm{~mm} /$ day $)$.

Analyzing the treatments for the cucumber it can be seen that is convenient to maintain frequent and light irrigations (T1) to guarantee adequate water availability in a constant and timely manner, allowing a high rate of daily evapotranspiration to be able to extract the water without difficulty. For the other hand, the T2 subjects the roots of the plants to compete with the colloids of the soil, interrupting the proper functioning of the plant with the decrease of the evapotranspiration, registering slight drops in the growth and productivity. Finally, the mean daily evapotranspiration obtained by the evaporimeter was $2.14 \mathrm{~mm}$ /day. Differences in values are observed in evapotranspiration calculated by indirect methods; this is due to the variation of the turbulence of the air above that surface (evaporimeter-plant), temperature and humidity adjacent. This shows that the plants respond to the same climatic variables as the evaporimeter tank, but several factors can introduce significant changes in water losses.

Table 2. Mean value and mean daily value of real crop Evapotranspiration (ETc) of creole cucumber, determined by water balance and evaporimeter

\begin{tabular}{|l|l|l|l|l|l|l|}
\hline \multirow{2}{*}{ Period } & \multicolumn{3}{|l}{ Water balance } & \multicolumn{2}{l|}{\begin{tabular}{l} 
Evaporimeter \\
\cline { 2 - 7 }
\end{tabular}} & \multicolumn{2}{|l|}{ Mean value } & \multicolumn{2}{l|}{ Mean daily } & $\begin{array}{l}\text { Mean } \\
\text { value }\end{array}$ & $\begin{array}{l}\text { Mean } \\
\text { daily value }\end{array}$ \\
\cline { 2 - 7 } & T1 & T2 & T1 & T2 & & \\
\hline 1 & 7.77 & 4.91 & 2.59 & 1.64 & 4.99 & 1.66 \\
\hline 2 & 8.21 & 7.48 & 2.74 & 2.49 & 5.46 & 1.82 \\
\hline 3 & 8.8 & 7.38 & 2.93 & 2.46 & 5.5 & 1.83 \\
\hline 4 & 8.7 & 8.61 & 2.9 & 2.87 & 6.48 & 2.16 \\
\hline 5 & 8.7 & 8.61 & 2.98 & 2.87 & 7.92 & 2.64 \\
\hline 6 & 8.94 & 8.64 & 3.4 & 2.88 & 4.79 & 1.6 \\
\hline 7 & 10.2 & 10.77 & 4.1 & 3.59 & 7.11 & 2.37 \\
\hline 8 & 12.33 & 11.23 & 4.1 & 3.74 & 5.33 & 1.78 \\
\hline 9 & 11.4 & 12.14 & 3.8 & 4.05 & 9.01 & 3.00 \\
\hline 10 & 10.44 & 10.89 & 3.48 & 3.63 & 5.24 & 1.75 \\
\hline 11 & 10.89 & 8.14 & 3.63 & 2.71 & 8.14 & 2.71 \\
\hline 12 & 10.29 & 8.6 & 3.43 & 2.87 & 8.61 & 2.87 \\
\hline 13 & 9.99 & 8.63 & 3.33 & 2.94 & 6.55 & 2.18 \\
\hline 14 & 8.9 & 8.56 & 2.97 & 2.85 & 7.1 & 2.37 \\
\hline 15 & 7.99 & 7.91 & 2.66 & 2.64 & 5.34 & 1.68 \\
\hline 16 & 5.21 & 5.1 & 2.61 & 2.55 & 4.98 & 1.42 \\
\hline & & & & & & \\
\hline
\end{tabular}

Table 3 shows the crop coefficient (Kc) for the creole cucumber. For T1 and T2, a mean Kc of 0.89 and 0.87 was obtained, respectively. The values obtained reflect the great influence of climate on the water requirements of the crop, reflecting the high evaporative capacity of the atmosphere. These values agree with those reported by (4). Analysis of variance in evapotranspiration did not show significant difference between treatments $(\mathrm{P}<0.05)$. This occurs because in the T1 soil is maintained at field capacity, allowing that the nutrients and water are eas- 
ily absorbed by the plants through the roots, presenting an adequate rate of transpiration. In the field capacity conditions, the soil particles exert little tension force in the water, which allows it to be easily removed from the ground under the action of wind and high temperatures, registering in the crop with this treatment a high rate of evapotranspiration. In T2, the water in the soil is under a greater force of tension, registering a movement of this towards the roots of the plant causing a decrease the transpiration by means of physiological processes like the stomatal self-regulation during the warmest hours of the day. The analysis of variance in the coefficient of evapotranspiration Kc did not show significant differences between the two treatments.

Table 3. Mean values of crop coefficient $(\mathrm{Kc})$ for creole cucumber

\begin{tabular}{|l|l|l|l|l|l|l|}
\hline \multirow{2}{*}{ Period } & \multicolumn{2}{l}{ ETc mean $(\mathrm{mm})$} & \multicolumn{2}{l}{$\begin{array}{l}\text { ETo mean } \\
(\mathrm{mm})\end{array}$} \\
\cline { 2 - 7 } & T1 & T2 & T1 & T2 & T1 & T2 \\
\hline 1 & 7.74 & 4.91 & 10.11 & 6.29 & 0.77 & 0.78 \\
\hline 2 & 8.21 & 7.48 & 9.61 & 8.9 & 0.85 & 0.84 \\
\hline 3 & 8.8 & 7.38 & 10.12 & 8.8 & 0.87 & 0.84 \\
\hline 4 & 8.7 & 8.61 & 9.56 & 9.78 & 0.91 & 0.88 \\
\hline 5 & 8.7 & 8.61 & 9.56 & 9.78 & 0.91 & 0.88 \\
\hline 6 & 8.94 & 8.64 & 9.83 & 9.49 & 0.91 & 0.91 \\
\hline 7 & 10.02 & 10.77 & 10.59 & 11.46 & 0.95 & 0.94 \\
\hline 8 & 12.31 & 11.23 & 12.84 & 11.82 & 0.96 & 0.95 \\
\hline 9 & 11.4 & 12.14 & 12.11 & 12.54 & 0.94 & 0.97 \\
\hline 10 & 10.44 & 10.89 & 10.76 & 11.49 & 0.97 & 0.95 \\
\hline 11 & 10.89 & 8.14 & 11.46 & 8.76 & 0.95 & 0.93 \\
\hline 12 & 10.29 & 8.6 & 11.62 & 10.31 & 0.89 & 0.83 \\
\hline 13 & 9.99 & 8.83 & 11.71 & 11.09 & 0.85 & 0.8 \\
\hline 14 & 8.9 & 8.5 & 10.35 & 10.31 & 0.86 & 0.83 \\
\hline 15 & 7.99 & 7.91 & 9.43 & 9.53 & 0.85 & 0.83 \\
\hline 16 & 5.21 & 5.1 & 6.2 & 6.22 & 0.84 & 0.82 \\
\hline & & & & & & \\
\hline
\end{tabular}

The average yields in 4 harvest were $20.26 \mathrm{t} / \mathrm{ha}(81.04$ $\mathrm{t} /$ ha-year) and $20.24 \mathrm{t} / \mathrm{ha}$ (80.96 t/ha-year) for T1 and T2, respectively, furthermore there is a strong relationship between water availability and productivity ${ }^{13}$. The analysis of variance did not show significant differences in production between the two treatments, which allows applying irrigate with any frequency. Due to the way in which the crop requires water (frequent and light irrigation), it is advisable to irrigate every day. Finally, the results of the research showed that it is possible to measure the crop evapotranspiration rates and determine the water requirements of the cucumber by means of drip irrigation ${ }^{8}$.

\section{Conclusions}

The main conclusions of the study may be summarized as follows:

- The values that affect the crop coefficient $(\mathrm{Kc})$ are mainly the characteristics of the crop, the dates of planting or sowing, the rhythm of development of the crop, the duration of the vegetative period, the climatic conditions especially during the first phase of growth and the frequency of irrigation or rainfall.

- The high yields achieved in the cultivation of Creole cucumber, make it profitable by applying drip irrigation, making it an effective way to improve the food regimen and life of the region.

- During periods of water scarcity, the supply of irrigation must be programmed according to the deficit of ETc.

\section{References}

1. Blanco FF, Folegatti MV. Evapotranspiration and crop coefficient of cucumber in greenhouse. Revista Brasileira de Engenharia Agricola e Ambiental. 2003 Aug; 7(2):285-91. Crossref

2. Ayas S, Demirtas C. Deficit irrigation effects on cucumber (Cucumis sativus L. Maraton) yield in unheated greenhouse condition. Journal of Food, Agriculture and Environment. 2009; 7(3-4):645-9.

3. Sousa VE, Marouelli WA, Coelho EF, Pinto JM, Coelho Filho MAC. Irrigacao e fertirrigaco em fruteiras e hortalicas. Embrapa Informacao Tecnologica. Brasilia: Emprapa; 2011. p. 1-771.

4. Edgar R, Andy R, Luis R, Jose S, Montilla E. Estimacion de las necesidades hidricas del cultivo de pepino (cucumis sativus 1.) Durante las diferentes etapas fenologicas, mediante la tina de evaporacion. Agricultura Andina. 2009; 16(1):56-69.

5. Rahil $\mathrm{MH}$, Qanadillo A. Effects of different irrigation regimes on yield and water use efficiency of cucumber crop. Agricultural Water Management. 2015 Jan; 148:10-5. Crossref

6. Chacon-Padilla K, Monge-Perez JE. Evaluacion de rendimiento y calidad de seis genotipos de pepino de frutos 
largos (Cucumis sativus L.) cultivados bajo invernadero en Costa Rica, durante la epoca seca. Revista Colombiana De Ciencias Horticolas. 2016 Jul; 10(2):323-32. Crossref

7. Douh B, Mguidiche A, Sami Bhouri K, Mohsen M, Harrabi $\mathrm{R}$, Abdelhamid B. Yield and water use efficiency of cucumber (Cucumis sativus L.) conducted under subsurface drip irrigation system in a Mediterranean climate. IOSR Journal of Environmental Science, Toxicology and Food Technology. 2013; 2(4):46-51. Crossref

8. Zhang Z, Liu S, Liu S, Huang Z. Estimation of cucumber evapotranspiration in solar greenhouse in Northeast China. Agricultural Sciences in China. Apr 2010; 9(4):512-8. Crossref

9. Cakir R, Kanburoglu-Cebi U, Altintas S, Ozdemir A. Irrigation scheduling and water use efficiency of cucumber grown as a spring-summer cycle crop in solar greenhouse.
Agricultural Water Management. Jan 2017; 180:78-87. Crossref

10. Marcano C, Acevedo I, Contreras J, Jiménez O, Escalona A, Pérez P. Crecimiento y desarrollo del cultivo pepino (Cucumis sativus L.) en la zona hortícola de Humocaro bajo, estado Lara, Venezuela. Revista mexicana de ciencias agrícolas. 2012, 3 (8), pp. 1629-36.

11. Maynard DN, Hochmuth GJ. Knott's Handbook for Vegetable Growers. 5th Edition. 2006. 1-621 p. Crossref

12. Instituto Geografico Agustin Codazzi (IGAC). Metodos analiticos del laboratorio de suelos. Igac. 2006. p. 1-648.

13. Oliveira EC, Carvalho de JA, da Silva WG, Rezende FC, Gomes LAA, de Jesus MCN. Analise produtiva e economica do pepino japones submetido a diferentes laminas de irrigacao. Rev Bras Eng Agricola e Ambient. Jul 2011; 15(7):702-8. Crossref 